\title{
THE EFFECT OF AGE ON CERVICAL CANCER SCREENING IN WOMEN AGED 20-29
}

\author{
Hasan Aykut Tuncer ${ }^{1}$ and Serap Firtına Tuncer ${ }^{2}$ \\ ${ }^{1}$ Department of Obstetrics and Gynecology, Division of Gynecological Oncology, \\ Akdeniz University School of Medicine Hospital, Antalya, Turkey; \\ ${ }^{2}$ Department of Obstetrics and Gynecology, Antalya Education \& Research Hospital, Antalya, Turkey
}

\begin{abstract}
SUMMARY - No definite consensus exists currently regarding the appropriate age at which to start cervical cancer screening. We analyzed the effectiveness of age in abnormal histology outcomes in women aged 20-29. Data on women aged 20-29 having undergone opportunistic cervical cancer screening with cytology during the 2014-2019 period were retrospectively reviewed. Based on cytology outcomes, human papillomavirus test results (if present), age and clinical decision, patients underwent either colposcopy or observation. The effects of age and other epidemiologic factors on histologic diagnoses of cervical intraepithelial neoplasia (CIN) or cancer [CIN (+)] were analyzed in univariate and binomial logistic regression analyses. Among 1649 women, $\mathrm{CIN}(+)$ lesions were observed in $61(3.7 \%)$ women. The occurrence of $\mathrm{CIN}(+)$ lesions increased 1.149 times each year; thus, women aged 25-29 were more likely to have CIN $(+)$ than those aged $20-24(4.4 \%$ vs. $2.1 \%$; $\mathrm{p}=0.019)$. A significant determinant of CIN $(+)$ was the increase in age, i.e. women aged 20-29. Accordingly, considering age is crucial for the diagnosis of $\mathrm{CIN}(+)$ in cancer screening.
\end{abstract}

Key words: Cervical cancer; Screening age; HPV; Cytology; Colposcopy

\section{Introduction}

Cervical cancer is the fourth most commonly diagnosed and the fourth leading cause of death in females ${ }^{1}$. It is estimated that almost 570,000 new cases of cervical cancer and 311,000 associated deaths among women occur worldwide each year ${ }^{1}$. In Turkey, cervical cancer is the $9^{\text {th }}$ most common cancer, with an estimated incidence rate of $4.3 / 100,000^{2}$. It is understood that regular cervical cancer screening promotes early detection of cervical premalignant lesions and decreases mortality rate from cervical cancer. However, there is no consensus regarding the starting age for cervical cancer screening worldwide. Starting screen-

Correspondence to: Hasan Aykut Tuncer, MD, Akdeniz Üniversitesi Tıp Fakültesi Hastanesi, Kadın Hastalıkları ve Doğum Ana Bilim Dalı, Jinekolojik Onkoloji Cerrahisi Bilim Dalı, Pınarbaşı Mahallesi, 07058 Konyaaltı, Antalya, Turkey

E-mail: aykuttuncer@hotmail.com

Received January 24, 2020, accepted February 12, 2020 ing at 20 years of age may have little effect on detecting cervical cancer but may carry potential harm due to the treatment of high-grade cervical lesions that may regress with time, leading to adverse pregnancy outcomes such as preterm birth and low birth weight ${ }^{3}$. On the other hand, starting cervical cancer screening at the age of 30 years may lead to missing cervical intraepithelial neoplasia (CIN) lesions that have the potential risk of developing into cervical cancer.

The age for starting cervical cancer screening is between 20-30 in most countries globally. Turkey boasts a national cervical cancer screening program involving human papillomavirus (HPV) testing starting at the age of 30 . For younger ages, opportunistic screening is available. Cervical cancer screening is individual-based and performed depending on the decisions of the clinicians and patients involved. There are limited data on the prevalence rates of CIN and cervical cancer in women aged 20-29 in Turkey. We therefore sought to analyze the prevalence of abnormal screening results 
among women aged 20-29 years in the Akdeniz University Department of Obstetrics and Gynecology to elucidate the prevalence of abnormal cytologic results not screened for in the national program. We also aimed to gather scientific evidence for the implementation of cervical cancer screening among women aged 20-29 by analyzing the effects of age and possible epidemiologic cofactors on developing colposcopy diagnosed abnormal histology outcomes.

\section{Patients and Methods}

After approval of the study was granted by the local institutional Ethics Committee (approval no. 818), we retrospectively investigated women aged 20-29 (<30) having undergone cervical cancer screening with cytology between 2014 and 2019. The study was performed in accordance with the ethical standards described in the appropriate version of the 1975 Declaration of Helsinki, as revised in 2000.

Patients with a known history of CIN or gynecologic cancer, and those that were pregnant were excluded from this study. If a woman underwent two or more cytologic investigations during the study period, the age at which abnormal cytology results were observed was taken into account. Conversely, if all cytology findings were normal, then the mean age among all the times the patient was examined was calculated and taken into account on data analysis. Only patients with satisfactory cytology outcomes were included in the analysis. If a patient had normal cytology but an absent/insufficient endocervical/transformation zone, she was excluded from this study.

Demographic data, marital status, past obstetric and gynecologic history, gravidity, parity, number of abortions, current use of a contraceptive method, smoking habit, cytology, HPV test results (if available), and cervical biopsy results were collected. Considering the need for colposcopy according to the American Society for Colposcopy and Cervical Pathology (AS$\mathrm{CCP}$ ) guidelines, women who had not undergone colposcopy were excluded from statistical analysis performed for the association of age and other characteristics with CIN lesions.

Liquid-based cytology was used in all women. Normal cytology was defined as negative for intraepithelial lesion or malignancy. Cytology results were re- ported according to the Bethesda classification, as follows: abnormal findings included atypical squamous cells of undetermined significance (ASC-US); atypical squamous cells suspicious for high-grade squamous intraepithelial lesions (ASC-H); low-grade squamous intraepithelial lesions (LSIL); high-grade squamous intraepithelial lesions (HSIL); atypical glandular cells (AGC); adenocarcinoma in situ; and invasive cancer.

The management of abnormal cytology results was performed according to the ASCCP guidelines. Based on cytology outcomes, HPV test results (if present), patient age and clinical decision, patients underwent either colposcopy or observation with repeat screening testing. According to this management protocol, women aged 21-24 with ASC-US or L-SIL cytology were those who underwent colposcopy (e.g., if a patient had postcoital bleeding, obvious cervical lesions, and condyloma accuminata, she underwent colposcopy); otherwise, the patient underwent repeat cytology at 12 months later. At 12 months, if the patient had ASC-H, AGC, or HSIL, colposcopy was performed, but if the findings were negative, ASC-US or LSIL without any clinical suspicion, then the patient underwent repeat cytology again 12 months later, and so forth. If the patient had ASC-US with negative HPV test results, she was allocated to the CIN (-) group. The women aged 25 or older with ASC-US cytology without any clinical suspicion underwent HPV testing (if available during the study period); otherwise, repeat cytology was planned at one year and colposcopy was performed according to cytology results at one year. The women aged 25 or older with LSIL cytology without any clinical suspicion underwent colposcopy alone or colposcopy in conjunction either with HPV testing or follow-up cytology at one year. Women of all ages with ASC-H or HSIL findings underwent colposcopy. Standard colposcopic techniques were used on colposcopy, including observing the cervix after the application of 3\% acetic acid and taking biopsies from all abnormal areas.

The prevalence of cytology findings was analyzed in the population of women in whom cytology was performed. Colposcopic biopsies were reported as normal (no CIN lesions), CIN grade 1, CIN grade 2, CIN grade 3 , and invasive cancer. CIN grade 1 lesions were also defined as histology-proven LSIL, while CIN grades 2 and 3 lesions were defined as histology-proven HSIL. 


\section{Statistical method}

Statistical Package for the Social Sciences version 23.0 for Windows software program (IBM Corp., Armonk, NY, USA) was used for statistical analyses. Frequencies of normal and abnormal cytology findings and HPV were calculated using descriptive statistics in the whole study population. The occurrence of histologically diagnosed CIN lesions or cancer was defined as the response variable [CIN (+)]. Continuous variables included age, gravidity, and parity. These parameters were evaluated by visual (e.g., histograms and probability plots) and analytical (KolmogorovSmirnov/Shapiro-Wilk test) methods to assess whether they were normally distributed or not. Abnormally distributed parameters were expressed as medians and percentiles, whereas normally distributed parameters were expressed as means. Categorical variables (e.g., any contraceptive method, smoking habit, age range 21-24 or 25-29) were expressed as numbers and frequencies. The $\chi^{2}$-test was used to evaluate the relationship of those categorical variables with the occurrence of CIN (+). Women with abnormal cytology who were neither followed-up with nor received colposcopy in the Akdeniz University Department of Obstetrics and Gynecology were not included in statistical analysis of CIN (+) occurrence.

A p-value of 0.25 on univariate analysis was considered as a restrictive alpha level. Therefore, parameters with $\mathrm{p}$-values $<0.25$ on univariate analysis were included in the binomial logistic regression analysis. The forward likelihood ratio method was used and $\mathrm{p}$ values $<0.05$ were defined as statistically significant in binomial logistic regression analysis.

\section{Results}

A total of 1756 women screened by cytology were evaluated in this study. Thirteen women with CIN diagnosis, nine women whose epidemiological characteristics could not be determined, three women with ovarian cancer diagnosis, two women with cervical cancer diagnosis, and one woman having undergone hysterectomy for benign reasons were excluded from the study. Thus, 1728 women with smear results were evaluated.

On cytologic examinations of 1728 women, 1521 (88.0\%) women were found to be normal, 130 (7.5\%) women were ASCUS, 55 (3.2\%) women were LSIL,
Table 1. Epidemiological and clinical parameters of study population

\begin{tabular}{|l|l|l|}
\hline Characteristic & Parameter & Value (\%) \\
\hline Age (years) & Median & 26 \\
& $25^{\text {th-75 }}$ th percentiles & $24-28$ \\
& $20-24$ & $523(31.7)$ \\
& $25-29$ & $1126(68.3)$ \\
\hline Parity & Median & 0 \\
& $25^{\text {th-75 }} 5^{\text {th }}$ percentiles & $0-1$ \\
\hline Marital status & Single & $596(36.1)$ \\
& Married & $1053(63.9)$ \\
\hline Smoking habit & Smoker & $197(11.9)$ \\
& Non-smoker & $1452(88.1)$ \\
\hline Contraception & No & $1560(94.6)$ \\
method & Oral contraceptive pills & $43(2.6)$ \\
& Intrauterine device & $36(2.2)$ \\
& Condom & $10(0.6)$ \\
\hline
\end{tabular}

$14(0.8 \%)$ women were ASCH, five (0.3\%) women were HSIL, and three $(0.2 \%)$ women were AGC. HPV was tested in 382 women and 95 (24.9\%) of these were HPV (+).

Seventy-nine women with abnormal cytology but who were neither followed-up with nor received colposcopy in the Akdeniz University Department of Obstetrics and Gynecology could not be evaluated on univariate analysis or subsequent regression analysis. Thus, the effects of age and epidemiological factors on CIN (+) was investigated in 1649 women aged 20-29. CIN (+) lesions were observed in 61 (3.7\%) women. Table 1 shows the epidemiological and clinical parameters of these 1649 women. Their median age was 26 years, with 1126 women being aged 25-29. Most of the women (94.6\%) were not using any medically prescribed contraceptive method.

Epidemiological and clinical parameters in patients with cytologically or colposcopically normal or histologically diagnosed CIN (+) lesions are presented in Table 2. In comparison with women aged 20-24, those aged 25-29 were more likely to have CIN (+) ( $4.4 \%$ vs. $2.1 \% ; \mathrm{p}=0.019)$. The parameters of age, parity, smoking habit, use of oral contraceptive pills, and use of intrauterine device were included in the binomial logistic regression analysis. The only significant determinant of CIN $(+)$ was the increase in age, thus the occurrence of CIN (+) lesions increased 1.149 times each year in women aged 20-29 (Table 3). 
Table 2. Epidemiological and clinical parameters in patients with cytologically or colposcopically normal or histologically diagnosed CIN (+) lesions

\begin{tabular}{|l|l|l|l|l|}
\hline \multirow{2}{*}{ Characteristic } & \multirow{2}{*}{ Parameter } & \multicolumn{2}{|l|}{ Cytology/colposcopy finding/biopsy (\%) } & Univariate analysis \\
\cline { 3 - 5 } & & Normal & CIN $(+)$ & p value \\
\hline Age (years) & Median & 26 & 27 & $0.019^{\mathrm{b}}$ \\
& IQR & 4 & 3 & \\
& $20-24$ & $512(97.9)$ & $11(2.1)$ & $0.019^{\mathrm{a}}$ \\
& $25-29$ & $1076(95.6)$ & $50(4.4)$ & \\
\hline Parity & Median & 0 & 0 & 0.012 \\
& IQR & 1 & 1 & $0.058^{\mathrm{a}}$ \\
\hline Smoking habit & Smoker & $185(93.9)$ & $12(6.1)$ & \\
\hline Marital status & Non-smoker & $1403(96.6)$ & $49(3.4)$ & $0.283^{\mathrm{a}}$ \\
\hline Use of oral contraceptive pills & Single & $570(95.6)$ & $26(4.4)$ & \\
\hline Use of intrauterine device & Married & $1018(96.7)$ & $35(3.3)$ & $0.211^{\mathrm{c}}$ \\
& Yes & $40(93.0)$ & $3(7.0)$ & \\
\hline
\end{tabular}

$\mathrm{CIN}(+)=$ cervical intraepithelial neoplasia or cancer; IQR = interquartile range; ${ }^{\mathrm{a}} \mathrm{Mann}$ Whitney $\mathrm{U}$ test; ${ }^{\mathrm{b}}$ Pearson's $\chi^{2}$-test; ${ }^{\mathrm{c} F i s h e r}$ exact test

Table 3. Logistic regression analysis of factors predictive of CIN (+)

\begin{tabular}{|c|c|c|c|c|c|c|c|c|}
\hline & \multirow{2}{*}{ Coefficient } & \multirow{2}{*}{$\mathrm{SE}$} & \multirow{2}{*}{ Wald } & \multirow{2}{*}{ df } & \multirow[b]{2}{*}{$\mathrm{p}$} & \multirow{2}{*}{ OR } & \multicolumn{2}{|c|}{$95 \%$ CI for OR } \\
\hline & & & & & & & Lower & Upper \\
\hline Age (years) & 0.139 & 0.056 & 6.078 & 1 & 0.014 & 1.149 & 1.029 & 1.284 \\
\hline
\end{tabular}

$\mathrm{SE}$ = standard error; $\mathrm{df}=$ degree of freedom; $\mathrm{OR}=$ odds ratio; $\mathrm{CI}=$ confidence interval; $\mathrm{CIN}(+)=$ cervical intraepithelial neoplasia grade 1 or higher; Hosmer and Lemeshow test value: 0.673

\section{Discussion}

This study analyzed cytology and histology outcomes in the context of examining the effects of age and epidemiologic cofactors on CIN $(+)$ in women aged 20-29. According to our results, while $12 \%$ of women had abnormal cytology results, HPV testing was positive in $24.9 \%$ of women aged $20-29$. We also analyzed the effect of age on the occurrence of CIN (+) lesions in women aged 20-29 and found a one-year increase in age in these women to increase the occurrence of CIN $(+)$ lesions 1.149 times.

Our study population was from the region of Turkey with one of the highest HPV rates ${ }^{4}$. In the 30-65 age group, the HPV (+) rate is $4.4 \%$ nationally in Turkey but $6.2 \%$ in Antalya ${ }^{4}$. In our study group, $24.9 \%$ of women aged 20-29 were HPV (+).

The reason for the high HPV (+) rate in our study as compared with data from the national HPV screen- ing initiatives is the fact that the prevalence of HPV in our region is highest in Turkey and the study population was of a younger age. Indeed, persistent HPV infection is mandatory for the development of CIN and cervical cancer ${ }^{5}$. HPV acquisition in a young female is believed to occur just after her becoming sexually active, although the majority of this infection or early lesions become undetectable within one to two years ${ }^{6,7}$. High-risk HPV infection is relatively more common in females aged 20-29, with the highest incidence rate of $43.4 \%$ observed among those aged 20-248. However, the incidence rate of cervical cancer is one of the lowest in this age group. This is because of the transient nature of HPV infection, and also because cervical cancer takes about 10 to 15 years after the onset of HPV infection to develop. Thus, women with the disease diagnosed at 30-40 years of age may have a history of CIN in their twenties. In parallel to HPV prevalence, $12 \%$ of our study group had abnormal cytology results. In a 
comprehensive study by the Turkish Cervical Cancer and Cervical Cytology Research Group, the abnormal cytology prevalence rate in women of all ages was $1.8 \%{ }^{9}$. Additionally, a $9 \%$ to $19 \%$ prevalence rate of abnormal cytology in adolescents and young adults has been reported in previous studies ${ }^{10,11}$. These higher rates of cytologic abnormalities as compared with adult population can be explained by the increased HPV infection rate at these ages.

Previous studies have shown that age plays an important role in the development of CIN and cervical cancer ${ }^{12-14}$. In our study, we found that women aged 25-29 in comparison with women aged 20-24 were more likely to have CIN (+) (4.4\% vs. 2.1\%; p=0.019). Logistic regression analysis revealed that the only determinant of CIN (+) was an increase in age. This means that the risk increase of CIN observed each year was valid for all ages in comparison with previous age. For example, women aged 27 were 1.149 times more likely to have CIN in comparison with women aged 26. Untreated CIN regresses, persists or progresses, and the rate of progression is higher in older women with CIN grades 2 and $3^{12}$. CIN lesions require close observation or treatment. Treatment is completed via excisional procedures when CIN grades 2 or 3 are diagnosed or when persistence of CIN grade 1 is observed. However, excisional procedures are related to adverse pregnancy outcomes; therefore, observation is another option for women planning to be pregnant in the future. With this strategy, unnecessary treatment is not applied to the lesions to force regression and the side effects of treatment are prevented. In an observational cohort study from the United States (US), the annual incidence of abnormal cytology and $\mathrm{CIN}$ in women of all ages who undergo routine cervical cancer screening is reported to be about $5 \%$ and $2.7 \%$, respectively ${ }^{13}$. The same research revealed that the most common age group demonstrating abnormal cytology results and CIN were those aged 20-2913. CIN grade 1 was most commonly diagnosed in women aged 20-24 (5.1/1000), while CIN grades 2 and 3 were most commonly diagnosed in women aged 25-29 $(4.1 / 1000)^{13}$. Similarly, Butorac et al. report that CIN was most commonly diagnosed in younger women and therefore surgical treatment is more commonly applied to women aged 25-35 in Croatia ${ }^{14}$. The rate of CIN in our study (36.9/1000) was high as compared with the previous research in women aged 20-29. We believe that our high rate of CIN recorded in this age group was due to the study population having the highest incidence rate of HPV in Turkey. The CIN incidence rates are decreasing in societies that include HPV vaccine on the vaccination schedule ${ }^{15}$. Thus, there should be new screening guidelines for cervical cancer implemented in those societies, including the screening starting age. In contrast, HPV vaccine is not included at this time in the national vaccination schedule in Turkey. Despite this, Turkey has already designated screening to begin at the age of 30 . Opportunistic screening, which some younger women may undergo, has been shown to have no benefit in preventing cervical cancer ${ }^{16}$. Thus, organized screening must be implemented if cervical cancer screening is suggested to be done in women aged 20-29. A similar effect of age increase on the prevalence of cervical premalignant lesions has also been documented for the progression of untreated CIN lesions via screening. Older patients have higher rates of progression and lower rates of regression. Among women aged $\leq 24,25-29,30-34$, $35-39$ and $\geq 40$, progression rate was $10.6 \%, 13.5 \%$, $17.1 \%, 10.8 \%$ and $24.9 \%$, respectively ${ }^{12}$. In the same study, it was shown that, independently of CIN grade and presence or absence of HPV lesions, the CIN lesion regression rate was reduced by $21 \%$ with each five-year age grouping ${ }^{12}$.

Guidelines around the world present different recommendations on the starting age for cervical cancer screening. The World Health Organization recommends that screening be initiated at the age of 30, while most European (e.g., France, Belgium, Ireland, Italy, Norway), Australian and Canadian guidelines recommend the age of 25 years as when to initiate screening $^{17-20}$. Separately, US guidelines recommend screening should start at 21 years of age $\mathrm{e}^{21}$. Korean guidelines also recommend that screening should begin at 20 years due to the country's increased occurrence of highgrade lesions and cervical carcinoma as compared with developed countries ${ }^{22}$. With these cut-off ages, many of these countries believe that the treatment of precancerous lesions during pregnancy will be prevented. In parallel to the screening guidelines of the countries, screening programs differ as well, and the starting age for screening is a controversial issue. Each country implements its cervical cancer screening policy depending upon its own cervical cancer statistics, internal dynamics, and HPV (+) rate. Moreover, HPV vaccine is in- 
cluded in the immunization schedule mostly depending on the economic power of the country.

Of note, Makkonen et al. showed that the performance of organized screening in Finland, which officially introduces screening at 30 years, had no protective effect on cervical cancer among women younger than 25; however, when performed at age 25-29, it decreased the risk of cervical cancer by $48 \%{ }^{16}$. In contrast, Andrae et al. showed that Sweden's national cervical cancer screening had a protective effect against cervical cancer among women aged 20-29. They pointed out that Sweden's cervical cancer screening by cytology approach reduced the rate of cervical cancer cases by about $58 \%$ in women aged $20-29^{23}$.

The aim of cervical cancer screening is to diagnose CIN before the onset of cancer. Thus, cervical cancer can be prevented by treatment of early lesions. The aim of studies analyzing the effectiveness of screening should not be focused on the detection rate of cancer. However, if we investigated the relationship between age and cervical cancer, we could see that the incidence of cervical cancer is related to the age of women. According to the International Agency for Research on Cancer, the estimated cervical cancer rates at ages 20, 25 and 30 years were about $0.30 / 100,000,1.82 / 100,000$ and $2.80 / 100,000$, respectively. Also, the increase in the rate of cervical cancer between age 20 and 25 was slightly higher than the increase recorded between age 25 and 30 years $^{24}$. In the United Kingdom (UK), cervical cancer incidence is highest in women aged 25-29 as compared with any other five-year period of a woman's life. The incidence gradually decreases until age 60-64 and then rises again ${ }^{25}$. The cervical cancer incidence rates per 100,000 women-years were 4.0 at age 20-24 but 20.3 at age $25-29^{25}$. In comparison, in the US, the cervical cancer incidence rate per 100,000 women-years was 1.40 at age $20-24$ but 5.94 at age $25-29^{26}$.

There are studies that address the roles of cofactors in the progression of cervical carcinoma in women of different age groups. In studies including adults older than 30, smoking, parity, and oral contraception and intrauterine device use were defined as cofactors for $\mathrm{CIN}$ and cervical cancer ${ }^{27-29}$. Among adolescents and young adults, no correlation was found between smoking or use of oral contraceptives and CIN and HPV ${ }^{30}$. However, we found no relationship between these cofactors and the occurrence of CIN in women aged 2029 either. Specifically, this may be due to the fact that temporary behavior of HPV in young women makes these cofactors ineffective in determining the progression of HPV to CIN and cervical cancer.

\section{Study limitations}

There were some limitations in our study that should be highlighted. Because it was a retrospective study, we were unable to question about the age of first sexual intercourse or the frequency and number of sexual partners of the women, which are the possible risk factors for HPV persistence in developing CIN and cervical cancer ${ }^{31}$. Another limitation was the lack of investigation of HPV subtypes, as a specific subtype may be more related to CIN development. It has been pointed out that the most carcinogenic subtypes (HPV subtypes 16 and 18) are most strongly related to highgrade precancerous lesions and cervical cancer in the 20-29 age group ${ }^{32}$. Moreover, HPV subtypes 16 and 18 cause CIN quicker and at younger ages, while other subtypes progress more slowly and cause CIN at older ages ${ }^{7}$. The final limitation of note was that the study population was from a single centre and the region (Antalya) displaying the upper limit of the HPV positivity in Turkey.

However, there also were significant advantages to this study. Methodologically, the women included in the study met the ASCCP guidelines. Also, the entire study population included women aged $<30$ who were not screened by the national cervical cancer screening initiative in Turkey. In this manner, the study offers valuable information about the results of smear, HPV, and colposcopy in this unscreened population.

\section{Conclusion}

According to our findings and those of previous studies, age plays an important role in the development of CIN (+). Thus, taking age in consideration is crucial in the diagnosis of CIN $(+)$ on cancer screening. Women aged 25-29 as compared to those aged 20-24 are two times more likely to have CIN (+). CIN $(+)$ lesions are 1.149 times more likely to develop with each one-year age progression. Although our study population did not represent the characteristics of the whole Turkey or the global population, our study population's HPV positivity, abnormal cytology, and CIN rates were similar or higher than those of other popu- 
lations that have undergone such screening. Therefore, starting screening at age 25 instead of age 30 should be considered in our region, and further extensive studies are needed to decide on the optimal age to implement cervical cancer screening.

\section{Acknowledgment}

We would like to thank all physicians, pathology and laboratory staff and assistant healthcare professionals who provided healthcare services to patients in this study.

\section{References}

1. Bray F, Ferlay J, Soerjomataram I, Siegel RL, Torre LA, Jemal A. Global cancer statistics 2018: GLOBOCAN estimates of incidence and mortality worldwide for 36 cancers in 185 countries. CA Cancer J Clin. 2018;68(6):394-424. DOI: 10.3322/ caac. 21492

2. TR Ministry of Health. Cancer Statistics of Turkey, Yearbook 2016. Available from: https://hsgm.saglik.gov.tr/depo/birimler/kanser-db/istatistik/Trkiye_Kanser_statistikleri_2016.pdf

3. Kyrgiou M, Koliopoulos G, Martin-Hirsch P, Arbyn M, Prendiville W, Paraskevaidis E. Obstetric outcomes after conservative treatment for intraepithelial or early invasive cervical lesions: systematic review and meta-analysis. Lancet. 2006; 367(9509):489-98. DOI: 10.1016/S0140-6736(06)68181-6

4. TR Ministry of Health Cancer Department's Publications and presentations; Cervical Cancer Screenings, Scanning with HPV and Turkey's National Screening Program. Available from:https://hsgm.saglik.gov.tr/depo/birimler/kanser-db/ yayinlar/sunular/Servikal_Patoloji_ve_Kolposkopi_Egitimi_18.01.2019/Nejat_izmir_Tarama_2019.pdf

5. Ho GY, Burk RD, Klein S, Kadish AS, Chang CJ, Palan P, et al. Persistent genital human papillomavirus infection as a risk factor for persistent cervical dysplasia. J Natl Cancer Inst. 1995;87(18):1365-71. DOI: https://doi.org/10.1093/jnci/87. 18.1365

6. Collins S, Mazloomzadeh S, Winter H, Blomfield P, Bailey A, Young LS, et al. High incidence of cervical human papillomavirus infection in women during their first relationship. BJOG. 2002;109(1):96-8. DOI: 10.1111/j.1471-0528.2002.01053.x

7. Rodriguez AC, Burk R, Herrero R, Hildesheim A, Bratti C, Sherman ME, et al. The natural history of human papillomavirus infection and cervical intraepithelial neoplasia among young women in the Guanacaste cohort shortly after initiation of sexual life. Sex Transm Dis. 2007;34(7):494-502. DOI: 10.1097/01.olq.0000251241.03088.a0

8. Hariri S, Unger ER, Sternberg M, Dunne EF, Swan D, Patel S, et al. Prevalence of genital human papillomavirus among females in the United States, the National Health and Nutrition Examination Survey,2003-2006.J Infect Dis. 2011;204(4):56673. DOI: 10.1093/infdis/jir341
9. Turkish Cervical Cancer and Cervical Cytology Research Group. Prevalence of cervical cytological abnormalities in Turkey. Int J Gynaecol Obstet. 2009;106(3):206-9. DOI: 10.1016 /j.ijgo.2009.04.003

10. Henrique LQ Campaner AB, d'Avila FS. Cervical cancer screening of adolescent should not be encouraged. J Low Genit Tract Dis. 2017;21(1):21-5. DOI:10.1097/LGT.00000000 00000273

11. Soren K, Kharbanda EO, Chen S, Westhoff C. A 6-year experience with Pap smears in an urban adolescent practice: the scope and burden of abnormalities. J Pediatr Adolesc Gynecol. 2009;22(4):217-22. DOI: https://doi.org/10.1016/j.jpag.2008. 05.005

12. Bekos C, Schwameis R, Heinze G, Gärner M, Grimm C, Joura $\mathrm{E}$, et al. Influence of age on histologic outcome of cervical intraepithelial neoplasia during observational management: results from large cohort, systematic review, meta-analysis. Sci Rep. 2018;8:6383. DOI:10.1038/s41598-018-24882-2

13. Insinga RP, Glass AG, Rush BB. Diagnoses and outcomes in cervical cancer screening: a population-based study. Am J Obstet Gynecol. 2004;191(1):105-13. DOI: 10.1016/j.ajog.2004. 01.043

14. Butorac D, Škrtić B, Čukelj M, Kuna K, Djaković I. Twentyyear experience with large loop excision of the transformation zone at Sestre milosrdnice University Hospital Centre. Acta Clin Croat 2019;58:463-6. DOI: 10.20471/acc.2019.58.03.09

15. Benard VB, Castle PE, Jenison SA, Hunt WC, Kim JJ, Cuzick $\mathrm{J}$, et al. Population-based incidence rates of cervical intraepithelial neoplasia in the human papillomavirus vaccine era. JAMA Oncol. 2017;3(6):833-7. DOI: 10.1001/jamaoncol.2016.3609

16. Makkonen P, Heinavaara S, Sarkeala T, Anttila A. Impact of organized and opportunistic Pap testing on the risk of cervical cancer in young women - a case-control study from Finland. Gynecol Oncol. 2017;147(3):601-6. DOI: 10.1016/j.ygyno.2017.09.010

17. WHO guidelines for screening and treatment of precancerous lesions for cervical cancer prevention. World Health Organization 2013. Available from: https://apps.who.int/iris/bitstream/ handle/10665/94830/9789241548694_eng.pdf;jsessionid=E7 5ADE34B4D4D9FE34D441ECD1A17B38? sequence=1.

18. Arbyn M, Anttila A, Jordan J, Ronco G, Schenck U, Segnan N, et al. European Guidelines for Quality Assurance in Cervical Cancer Screening. Second edition -summary document. Ann Oncol. 2010;21:448-58. DOI: 10.1093/annonc/mdp471

19. Australian Government Department of Health. National Cervical Screening Program. Available from: http://www.cancerscreening.gov.au/internet/screening/publishing.nsf/Content/ cervical-screening.

20. Canadian Task Force on Preventive Health Care. Recommendations on screening for cervical cancer. CMAJ.2013;185(1):3545. DOI: $10.1503 / \mathrm{cmaj} .121505$

21. Saslow D, Solomon D, Lawson HW, Killackey M, Kulasingam SL, Cain JM, et al. American Cancer Society, American Soci- 
ety for Colposcopy and Cervical Pathology, and American Society for Clinical Pathology screening guidelines for the prevention and early detection of cervical cancer. J Low Genit Tract Dis. 2012;16(3):175-204. DOI: 10.1097/LGT.0b013 e31824ca9d5

22. KJ Min, YJ Lee, M Suh, CW Yoo, MC Lim, J Choi, et al. The Korean guideline for cervical cancer screening. J Gynecol Oncol. 2015;26(3):232-9. DOI: 10.3802/jgo.2015.26.3.232

23. Andrae B, Kemetli L, Sparén P, Silfverdal L, Strander B, Ryd $\mathrm{W}$, et al. Screening-preventable cervical cancer risks: evidence from a nationwide audit in Sweden. J Natl Cancer Inst. 2008; 100(9):622-9. DOI: 10.1093/jnci/djn099

24. Bray F, Colombet M, Mery L, Piñeros M, Znaor A, Zanetti R, Ferlay J, editors. Cancer Incidence in Five Continents, Vol. XI (electronic version). Lyon: International Agency for Research on Cancer, 2017. Available from: http://ci5.iarc.fr.

25. Cancer Research UK. Cervical cancer incidence statistics 2014-2016. Available from: https://www.cancerresearchuk.org /health-professional/cancer-statistics/statistics-by-cancer-type /cervical-cancer/incidence\#heading-One.

26. Benard VB, Watson M, Castle PE, Saraiya M. Cervical carcinoma rates among young females in the United States. Obstet Gynecol. 2012;120(5):1117-23. DOI: 10.1097/AOG.0b013 e31826e 4609

27. Averbach S, Silverberg MJ, Leyden W, Smith-McCune K, Raine-Bennett T, Sawaya GF. Recent intrauterine device use and the risk of precancerous cervical lesions and cervical cancer. Contraception. 2018;98(2):130-4. DOI: 10.1016/j.contraception.2018.04.008

28. Jensen KE, Schmiedel S, Norrild B, Frederiksen K, Iftner T, Kjaer SK. Parity as a cofactor for high-grade cervical disease among women with persistent human papillomavirus infection: a 13-year follow-up. Br J Cancer. 2013;108:234-9. DOI: 10.1038/bjc.2012.513

29. Kjellberg L, Hallmans G, Ahren AM, Johansson R, Bergman F, Wadell G, et al. Smoking, diet, pregnancy and oral contraceptive use as risk factors for cervical intra-epithelial neoplasia in relation to human papillomavirus infection. $\mathrm{Br} \mathrm{J}$ Cancer. 2000;82(7):1332-8. DOI: 10.1054/bjoc.1999.1100

30. Frega A, Stentella P, De Ioris A, Piazze JJ, Fambrini M, Marchionni $\mathrm{M}$, et al. Young women, cervical intraepithelial neoplasia and human papillomavirus: risk factors for persistence and recurrence. Cancer Lett. 2003;196(2):127-34.

31. Huică I, Iancu IV, Botezatu A, Pleşa A, Socolov D, Teleman S, et al. Factors associated with persistence of HPV genital infection in a small cohort of Romanian women. Acta Clin Croat. 2019;58:410-6. DOI: 10.20471/acc.2019.58.03.02

32. Onuki M, Matsumoto K, Satoh T, Oki A, Okada S, Minaguchi $\mathrm{T}$, et al. Human papillomavirus infections among Japanese women: age-related prevalence and type-specific risk for cervical cancer. Cancer Sci. 2009;100(7):1312-6. DOI: 10.1111/ j.1349-7006.2009.01161.x

Sažetak

\section{UČINAK DOBI NA PROBIR RAKA VRATA MATERNICE KOD ŽENA U DOBI OD 20-29 GODINA}

\section{H. A. Tuncer i S. Firtina Tuncer}

Zasad ne postoji konsenzus oko odgovarajuće dobi u kojoj treba započeti probir raka grlića maternice. Analizirali smo učinak dobi na nenormalne histološke ishode kod žena u dobi od 20-29 godina. Retrospektivno su pregledani podaci žena u dobi od 20 do 29 godina kod kojih je probir oportunističkog raka grlića maternice s citologijom izvršen u razdoblju od 2014. do 2019. godine. Na temelju rezultata citologije, rezultata ispitivanja humanog papilomavirusa, dobi i kliničke odluke bolesnice se podvrgavaju kolposkopiji ili promatranju. Učinci dobi i drugih epidemioloških čimbenika na histološke dijagnoze cervikalne intraepitelijske neoplazije (CIN) ili karcinoma [CIN (+)] analizirani su univarijatnom i binomialnom logističkom regresijskom analizom. Između 1649 žena CIN (+) lezije zabilježene su kod $61(3,7 \%)$ žene. Pojava CIN (+) lezija povećavala se 1149 puta svake godine; stoga je vjerojatnije da su žene u dobi od 25 do 29 godina imale CIN (+) nego one u dobi od

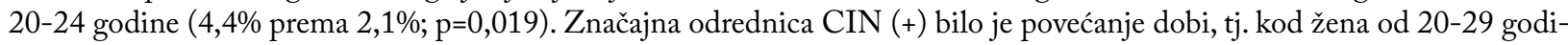
na. Uzimanje dobi u obzir presudno je u dijagnozi CIN $(+)$ u probiru raka.

Ključne riječi: Rak grlića maternice; Dob probira; HPV; Citologija; Kolposkopija 